\title{
Postfire Plant Establishment: THe EfFects of ENVIronment, Prefire VEGETATION, FIRE SEVERITY, AND LANDSCAPE POSITION
}

\author{
KATHLEEN M. DOYLE $\downarrow$ DENNIS H. KNIGHT \\ DEPARTMENT OF BOTANY ^ UNIVERSITY OF WYOMING \\ LARAMIE
}

\section{$\downarrow \quad$ INTRODUCTION}

The initial species composition and conditions following disturbance are crucial to determining the long-term development of vegetation (Egler 1954, Glenn-Lewin et al. 1992).

Thus, an understanding of early succession can provide insights into the mosaic of vegetation types that will emerge on a landscape. Observations in the Rocky Mountains and elsewhere indicate that postfire vegetation patterns vary considerably. It is now known that numerous factors simultaneously contribute to the species composition of pioneer vegetation (Stahelin 1943, Cattelino et al. 1979, Glenn-Lewin 1980, Noble and Slatyer 1980, Keever 1983, Walker and Chapin 1987, Pickett 1989, Westoby et al. 1989, Glenn-Lewin et al. 1992), and often different patterns of early succession are possible even on sites that are similar. While research on the distribution of late successional vegetation along environmental and disturbance gradients has been a dominant theme in plant ecology (Daubenmire 1943, Whittaker 1956, Despain 1973, Loope and Gruell 1973, Whipple and Dix 1979, Peet 1981, Romme and Knight 1981, Wentworth 1981, Veblen 1986, Allen and Peet 1990), few studies have directly investigated the factors that affect the distribution of pioncer plant communities. Moreover, the influence of landscape structure on the development of vegetation mosaics has only recently been considered (Milne and Forman 1986, Turner et al. unpublished manuscript). Studies designed to understand vegetation patterns following disturbance could be improved by considering site history and the character of the surrounding landscape as well as the effects of site features.

We have initiated research to consider the effect of various spatial, historical and site factors on early postfire vegetation in Grand Teton Naticnal Park (GTNP) and the adjrcent Bridger-Teton National Forest. Specifically, we are studying the relationships between characteristics of early succession and fire severity, geologic substrate, soil characteristics, mean burn patch size, prefire canopy composition, cone serotiny, topographic position, distance to unburned vegetation, and the vegetation composition and fire severity of the surrounding landscape. Our research objectives are to: 1) determine the range of variability in the patterns of early postfire succession; 2) determine which environmental and historical variables are most important in controlling vegetation development following fire; 3) elucidate the importance of landscape position and between-patch interactions during early postfire succession; 4) develop a series of multivariate models that will predict the characteristics of early succession in different situations; 5) project, based on existing literature, the 
most probable trajectorics of each pionecr : community type.

An important component of our rescarch is to examine the influence of landscape context on early successional vegetation. Understanding and predicting the bchavior of organisms requires the consideration of a broad environmental matrix, not simply the autecology of the organisms (Rowe 1981). According to Glenn-Lewin and van der Maarel (1992), spatial attributes such as landscape complexity, community isolation, and the spatial scale of disturbance are important factors influencing succession. We will use GRASS-GIS, to better understand the relationship between site characteristics and pioneer vegetation pattern (Davis and Dozier 1990, Davis and Goctz 1990) as well as to elucidate the importance of landscape position in early succession.

\section{$\uparrow \quad$ STUDY AREA}

A large number of geologic, topographic and hydrologic controls occur in close proximity in the Teton region. Much of the variability in site conditions that is characteristic of the Teton region is represented in 6 sites that have burned during the last two decades. The burns we are studying are known as the 1988 Huck Fire, the 1988 Hunter Fire, the 1987 Dave Adams Hill Fire, the 1985 Beaver Creek Fire, the 1981 Mystic Isle Fire, and the 1974 Waterfalls Canyon fire. The fires range in size from a minimum of 400 ha for the Beaver Creek Fire to greater than 32,400 ha for the Huck Fire. Elevation within the various burns ranges from approximately $2040 \mathrm{~m}$ to $2900 \mathrm{~m}$. Fire severity within each burn varies from severe crown burning to light surface burns. The majority of the region's major vegetation types are represented within the burns.

A variety of different substrate types are exposed within the six burned areas (Table 1). For example, within the Waterfalls Canyon fire are some of the oldest rocks of the Tetons, Precambrian gneiss, as well as sandstone, limestone and silistone dating to the Paleozoic Era and glaciai deposits dating to the Quaternary. Glacial deposits also are found in the Mystic Isle and Beaver Creek sites. Within the boundaries of the Hunter, Dave Adams Hill, and Huck fires are volcanic substrates, landslide debris, and different Mesozoic sedimentary rocks (including shales, sandstone, dolomitic siltston: and claystone; Love et al. 1992).

\begin{tabular}{|c|c|c|c|c|c|c|c|}
\hline Substrate Type & Huck & Hunt & WCF & DAH & Mys & $\mathrm{BC}$ & $\Sigma$ \\
\hline Glacial Drif/Glacial Debris & 4 & 1 & 8 & 3 & 12 & 9 & 37 \\
\hline Landslide Debris & 5 & 4 & 1 & 4 & & & 14 \\
\hline $\begin{array}{l}\text { Sedimentary } \\
\text { (non calcareous) }\end{array}$ & 8 & 1 & 1 & & & & 10 \\
\hline $\begin{array}{l}\text { Sedimentary } \\
\text { (with calcareous layers) }\end{array}$ & 1 & 3 & 1 & 2 & & & 7 \\
\hline Volcanic tuff & 7 & & & 1 & & & 8 \\
\hline Precumbrian Gneiss & & & 2 & & & & 2 \\
\hline $\begin{array}{l}\text { Huck = Huck Fire } \text { Hunt }=\mathrm{H} \\
\text { DAH = Dave Adams Hill Fir } \\
\text { BC = Beaver Creek Fire. }\end{array}$ & $\begin{array}{l}\text { ire; } W \\
S=M\end{array}$ & $\begin{array}{l}\text { VCF = } \\
\text { Aystic I }\end{array}$ & $\begin{array}{l}\text { Waterf } \\
\text { Isle Fire }\end{array}$ & $\begin{array}{l}\text { falls } \mathrm{Ca} \\
\text { re; and }\end{array}$ & anyon & Fire & \\
\hline
\end{tabular}

\section{METHODS}

\section{VEGETATION DATA}

We have adopted a standard sampling design whereby three rectangular plots ( $30 \mathrm{~m} \times 5 \mathrm{~m}$ ) are located within each stand, although the number and size of plots varies depending on seedling density, patch size, and variability within the stand. To sample the composition of the understory, ten quadrants $(50 \mathrm{~cm} \times 20 \mathrm{~cm})$ are sampled within each plot. A complete species list has been compiled for each plot and the following plant data have been obtained:

a. Postfire tree establishment and survivorship: The density and height class by species of all live tree seedlings and saplings that established following the fire. For each species, the number of individuals that appear to have survived the fire (based on estimating tree age) have been recorded.

b. Estimate of prefire vegetation: The $\mathrm{dbh}$ (at $1.37 \mathrm{~m}$ ) of all standing dead trees by species. Wood samples have been collected for anatomical an.lysis to verify the identification of dead trees. Wherever possible, the understory composition of nearby unburned forests (with similar site characteristics) has been recorded.

c. Percent cone serotiny: The prefire serotiny of $P$. contorta, if present, has been estimated 
using the techniques developed by Tinker et al. (1994) or by determining percent serotiny in nearby unburned stands that are similar in site characteristics.

d. Percent cover of understory species: The percent cover of all herbaceous and shrub spccies has been estimated by cover class using the Daubenmire canopy coverage method (Daubenmire 1959), and the percent cover of all large shrub species has been estimated using the line-intercept method (MuellerDombois and Ellenberg 1974).

\section{ENVIRONMENTAL DATA}

In addition to plant data, the following environmental data have been collected for each plot:

a. Slope, aspect, elevation, and landform type [concave slope, ridgetop etc].

b. Distance to unburned forest, distance to ridgetop, distance to stream [either measured or estimated from topographic maps or acrial photos].

c. Percent of the soil surface that is bedrock, boulders, cobbles, gravel, soil, and dead wood.

d. Geologic substrate and soil type [determined from field inspection and available maps, e.g., Young (1982), Love et al. (1992)].

e. Fire severity, classified as severe, moderate or light [the criteria used to classify fire severity includes the degree to which branches were consumed by the fire, the consumption of leaf litter, charring of logs on the ground, and the density of surviving trees within the stand; See Bradley et al. (1992)].

f. Soil analyses [three soil samples have been collected and pooled for each plot for subsequent analysis of texture and chemical composition].

g. Weather patterns for the years following each fire [compiled from data collected at weather stations in GTNP].

\section{DEVELOPMENT OF GIS DATABASES}

A primary goal of our research is to demonstrate the correspondence that exists between early successional vegetation patterns and environmental and landscape features. To understand these relationships and to test our hypotheses, we will use a varicty of techniques including GRASS-GIS, multivariate analyses, and statistics.
The following map layers will be included in the GRASS-GIS databases: elevation, aspect, slope (derived from a digital elevation model), geology, soils, hydrology, habitat type (available for all but the Hunter Fire), prefire vegetation type, and burn pattern (digitized from aerial photography). Vegetation and other environmental data from stands that we sample will also be added to the databases. From the original maps, measures of landscape structure will be generated using the r.le programs developed by Baker and Cai (1992), including diversity of vegetation types, mean patch size, dominance of burn severity class, distance to streams, distance to ridgetop, and distance to unburned forest.

\section{PROGRESS REPORT}

In a previous study (Doyle 1994), we analyzed data collected from permanent plots located in severe and moderate burns of the 1974 Waterfalls Canyon Fire in GTNP. Qualitative differences in species richness, life-history characteristics, percent cover of the understory, and density of postrire tree establishment were observed between areas that burned with different intensity. For both moderately and severely burned areas, the initial floristic composition appears to be important in shaping long-term development of the vegetation. Based on a comparison of the burned areas with older adjacent stands, various pathways of succession could be identified.

While conducting the Waterfalls Canyon study, we realized that a few permanent plots did not represent the wide range of variability in post-fire succession found in GTNP. Thus, during the summers of 1992-1994, we collected data from stands that had burned within the last two decades. These 80 stands represent much of the topographic and geologic variability within the six study areas (Table 1). In 1994, in addition to sampling 17 new stands, we collected additional data from previously sampled stands. These data include information on burn severity, as well as prefire stand characteristics such as percent serotiny and species composition prior to fire.

The following maps have been digitized and encompass most of the area within the six burned arcas: geology, habitat type, vegetation cover type, soils, clevation, aspect, slope, and hydrology. Also, 
using GRASS-GIS we have completed a preliminary landscape classification of the Dave Adams Hill Fire. Maps of geology, slope, aspect, elevation and burn mosaic were used to classify the landscape and the resulting classification appeared to be ecologically meaningful. We are continuing to digitize the burn mosaic from aerial photos for each of the other five study areas, and will be developing a landscape classification for each of the six study areas using the following map layers: geology, soils, slope, aspect, elevation, burn mosaic, distance to streams, and prefire vegetation.

In 1995 we will finish our data collection and concentrate on data analysis and development of our GIS database. We expect that the results of this research will provide a better understanding of vegetation patterns in the region and the influence of landscape context on early successional vegetation after fire. Our study complements ongoing research being conducted in Yellowstone National Park and will aid resource managers in managing for natural ecosystem processes.

\section{ACKNOWLEDGEMENTS}

This research has been supported by grants from the UW-NPS Research Station and the NPSRocky Mountain Regional Office. The accommodations and facilities provided by the UW. NPS Research Station are gratefully acknowledged. We also appreciate the assistance and logistical support provided by Grand Teton National Park and the Bridger-Teton National Forest. We thank Laura Archer, Joan Doyle, James Graves, James Krumm, Kevin Vaughan and Susan Wiser for help with fieldwork.

\section{Literature Cited}

Allen, R. B., and R. K. Peet. 1990. Gradient analysis of forests of the Sangre de Cristo Range, Colorado. Canadian Journal of Botany 68: 193-201.

Baker, W. L., and Y. Cai. 1992. The r.le programs for multiscale analysis of landscape structure using the GRASS geographical information system. Landscape Ecology 7 : 291-302.
Bradley, A. F., W. C. Fischer, and N. V. Noste. 1992. Fire ecology of the forest habitat types of castern Idaho and western Wyoming. USDA Forest Service, General Technical Report INT-290.

Cattelino, P. J., I. R. Noble, R. O. Slatyer, and S. R. Kessell. 1979. Predicting the multiple pathways of plant succession. Environmental Management 3: 41-50.

Daubenmire, R. 1943. Vegetation zonation in the Rocky Mountains. Botanical Review 9: 325-393.

Daubenmire, R. 1959. A canopy-coverage method of vegetational analysis. Northwest Science 33: $43-64$

Davis F. W., and J. Dozier. 1990. Information analysis of a spatial data base for ecological land classification. Photogrammetric Engineering and Remote Sensing 56: 605613.

Davis, F. W., and S. Goctz. 1990. Modeling vegetation pattern using digital terrain data. Landscape Ecology 4: 69-80.

Despain, D.G. 1973. Vegetation in the Big Horn Mountains, Wyoming, in relation to substrate and climate. Ecology 43: 329355.

Doyle, K. M. 1994. Succession following the 1974 Waterfalls Canyon Fire, Grand Teton National Park, Wyoming. M.S. Thesis, Botany Department, University of Wyoming, Laramie.

Egler, F. E. 1954. Vegetation science concepts I. Initial floristic composition, a factor in oldfield vegetation development. Vegetatio 4: 412-417.

Glenn-Lewin, D. C. 1980. The individualistic nature of plant community development. Vegetatio 43: 141-146. 
Glenn-Lewin, D. C., R. K. Peet and T. T. Veblen. 1992. Plant succession: theory and prediction. Chapman and Hall, New York.

Glenn-Lewin, D.C., and E. van der Maarel. 1992. Patterns and processes of vegetation dynamics. In Plant succession, theory and prediction. Edited by D.C. Glenn-Lewin, R.K. Peet, and T.T. Veblen. Chapman and Hall, New York. pp. 11-59.

Keever, C. 1983. Retrospective view of old-field succession after 35 years. American Midland Naturalist 110: 397-404.

Loope, L. L., and G. E. Gruell. 1973. The ecological role of fire in the Jackson Hole Area, Northwestern Wyoming. Quaternary Research 3: 425-443.

Love, J. D., J. C. Reed, Jr., and A. C. Christiansen. 1992. Geologic map of Grand Teton National Park, Teton County, Wyoming. U.S. Department of the Interior, U.S. Geological Survey.

Milne, B. T., and R. T. T. Forman. 1986. Peninsulas in Maine: Woody plant diversity, distance, and environmental patterns. Ecology 67: 967-974.

Mueller-Dombois, D., and H. Ellenberg. 1974. Aims and methods of vegetation ecology. John C. Wiley \& Sons, New York.

Noble, I. R., and R. O. Slatyer. 1980. The use of vital attributes to predict successional changes in plant communities subject to recurrent distrubances. Vegetatio 43: 5-21.

Peet, R. K. 1981. Forest vegetation of the Colorado Front Range. Vegetatio 45: 3-75.

Pickett, S. T. A. 1989. Space-for-time substitution as an alternative to long-term studies. In Long term studies in ecology, approaches and alternatives. Edited by G.E. Likens. Springer-Verlag, New York. pp. 110-135.

Romme, W. H., and D. H. Knight. 1981. Fire frequency and subalpine forest succession along a topographic gradient in Wyoming. Ecology 62: 319-326.
Rowe, J. S. 1981. Concepts of fire effects on plant individuals and species. $\underline{\text { In }}$ The role of fire in northern circumpolar ecosystems. Edited by R. W. Wein and D. A. MacLean. John Wiley and Sons, New York. pp. 135-154.

Stahelin, R. 1943. Factors influencing the natural restocking of high altitude burns by coniferous trees in the Central Rocky Mountains. Ecology 24: 19-30.

Tinker, D. B., W. H. Romme, W. W. Hargrove, R. H., Gardner, and M. G. Turner. 1994. Landscape-scale heterogeneity in lodgepole pine serotiny. Canadian Journal of Forest Research 24: 897-903.

Turner, M. G., W. H. Romme, R. H. Gardner, and W. W. Hargrove. Burn severity and plant reestablishment on a subalpine plateau in Yellowstone National Park. (unpublished manuscript).

Veblen, T. T. 1986. Age and size structure of subalpine forests in the Colorado Front Range. Bulletin of the Torrey Botanical Club 113: 225-240.

Walker, L. R. and F. S. Chapin. 1987. Interactions among processes controlling successional change. Oikos 50: 131-135.

Wentworth, T. R. 1981. Vegetation on limestone and granite in the Mule Mountains, Arizona. Ecology 62: 469-482.

Westoby, M., B. Walker, and I. Noy-Meir. 1989. Opportunistic management for rangelands not at equilibrium. Journal of Range Management 42: 266-274.

Whipple, S. A., and R. L. Dix. 1979. Age structure and successional dynamics of a Colorado subalpine forest. American Midland Naturalist 101: 142-158.

Whittaker, R. H. 1956. Vegetation of the Great Smoky Mountains: Ecological Monographs 26: $1-80$.

Young, J. F. 1982. Soil survey of Teton County, Wyoming, Grand Teton National Park area. Soil Conservation Service, USDA. 